\title{
KEMAMPUAN PEMECAHAN MASALAH SISWA BERGAYA KOGNITIF IMPULSIF BERDASARKAN TAKSONOMI SOLO
}

\author{
Oce Datu Appulembang, Kimura Patar Tamba \\ Universitas Pelita Harapan, MH Thamrin Boulevard 1100, Banten, Indonesia \\ E-mail: oce.appulembang@uph.edu
}

\begin{abstract}
Abstrak
Kemampuan pemecahan masalah antara subjek reflektif dan impulsif dari beberapa penelitian memunculkan bahwa subjek reflektif selalu lebih unggul daripada subjek impulsif. Tujuan dari penelitian ini adalah mengidentifikasi dan mendeskripsikan kemampuan pemecahan masalah siswa dengan gaya kognitif impulsif dalam memecahkan masalah tes superitem serta karakteristiknya. Penelitian ini merupakan penelitian deskriptif kualitatif. Teknik pengumpulan data yang digunakan adalah tes MFFT, tes superitem dan wawancara. Berdasarkan hasil tes superitem tersebut menampilkan bahwa kedua subjek impulsif memiliki perbedaan dalam mencapai level berpikir kemampuan pemecahan masalah. Subjek Impulsif-01 dapat mencapai semua level berpikir berdasarkan taksonomi SOLO sedangkan subjek impulsif-02 hanya mampu menyelesaikan masalah pada level unistruktural. Meskipun penelitian menunjukkan bahwa subjek impulsif-01 memiliki karakteristik cepat, kurang cermat, kurang teliti dan terkesan terburu-buru dalam menyelesaikan masalah namun subjek dapat menyelesaikan hingga tahap extended abstrak. Subjek impulsif-02 mampu menghubungkan dengan membuat dugaan dalam menyelesaikan masalah hanya saja ketidakmampuan dalam memecahkan masalah ini dikarenakan tidak memahami masalah.
\end{abstract}

Kata Kunci: Gaya Kognitif, Impulsif, Pemecahan Masalah, Tes Superitem

\begin{abstract}
The problem-solving ability between reflective and impulsive subjects from several studies shows that reflective subjects are always superior than impulsive subjects. The purpose of this study was to identificate and to describe students' problem-solving abilities with impulsive cognitive style in solving superitem test problems and their characteristics. This research is a qualitative descriptive study. The data collection techniques used were the MFFT test, the superitem test, and interviews. Based on the results of the superitem test, it shows that the two impulsive subjects have differences in achieving the level of problem-solving ability thinking. Impulsive-01 subjects can reach all thinking levels based on SOLO taxonomy while impulsive-02 subjects can only solve problems at the unistructural level. Although the research shows that the impulsive-01 subject has the characteristics of being fast, less accurate, less thorough, and seeming rushed in solving problems, the subject can finish up to the extended abstract level. The impulsive-02 is able to connect by making assumptions in solving the problem, it's just that the inability to solve this problem due to not understand the problem.
\end{abstract}

Keywords: Cognitive Style, Impulsive, Problem Solving, Superitem Test

\section{PENDAHULUAN}

Pemecahan masalah merupakan suatu kemampuan yang perlu dimiliki oleh setiap orang. Pemecahan masalah merupakan suatu kegiatan berpikir tingkat tinggi dan 
merupakan suatu usaha mencapai tujuan untuk mencari jalan keluar dari suatu masalah Maimunah et al. (2016). Lebih lanjut, Anggraeni et al., (2019) mengatakan bahwa pemecahan masalah merupakan suatu proses atau upaya seseorang untuk mencari penyelesaian dari kesulitan yang ada melalui penemuan masalah, penetapan kaidahkaidah dan konsep yang telah dimiliki sebelumnya. Oleh sebab itu dalam suatu pembelajaran matematika perlu diberikan suatu pengalaman pemecahan masalah kepada siswa.

Menurut Widjajanti (2009) salah satu tujuan belajar matematika bagi siswa adalah agar mempunyai kemampuan atau keterampilan dalam memecahkan masalah atau soalsoal matemtaika sebagai sarana baginya untuk mengasah penalaran yang cermat, logis, kritis, analitis dan kreatif. Hal serupa pun dikemukakan Komalasari (2019), bahwa pembelajaran kemampuan pemecahan masalah memiliki manfaat salah satunya yaitu siswa dapat melihat relevansi antara pembelajaran matematika dengan mata pelajaran lainnya serta dalam kehidupan sehari-hari.

Pembelajaran matematika Menurut Erviana (2019), memiliki tujuan agar siswa dapat bersikap ingin tahu, perhatian, pantang menyerah, ulet dan percaya diri dalam memecahkan suatu masalah. Oleh sebab itu, guru dituntut akan kesiapannya menghadapi perbedaan kemampuan pemecahan masalah, berpikir kreatif, serta perbedaan dalam memperoleh, menyimpan, serta menerapkan pengetahuan (Fadiana, 2016). Adapun perbedaan dalam menyelesaikan masalah ini terkait dengan gaya kognitif seseorang. Bagaimana siswa belajar dan menyelesaikan masalah sangat bergantung kepada hubungan antara kognisi dan kepribadian seseorang yang disebut sebagai gaya kognitif (Nurmutia, 2019). Lebih lanjut dinyatakan bahwa terdapat hubungan positif yang kuat antara gaya kognitif dan kemampuan pemecahan masalah matematis siswa.

Gaya kognitif merupakan suatu cara yang dilakukan oleh seseorang dalam menerima dan mengorganisasi informasi sekitarnya (Rahmatina et al., 2014). Terdapat beberapa gaya kognitif, salah satunya adalah gaya kognitif konseptual tempo. Gaya kognitif tempo terdiri gaya kognitif impulsif yaitu gaya kognitif dengan kecenderungan bereaksi dengan sangat cepat namun kurang tepat, dan gaya kognitif reflektif yaitu kecenderungan beraksi dengan lebih lambat, namun tepat (Appulembang, 2017). Siswa yang bergaya kognitif impulsif itu memiliki karakteristik cepat menjawab masalah, tetapi kurang cermat, sehingga jawaban cenderung salah. Sebaliknya, siswa bergaya kognitif 
reflektif memiliki karakteristik lambat menjawab masalah, tetapi cermat, sehingga jawaban cenderung benar (Soemantri, 2018).

Dalam menganalisis kemampuan pemecahan masalah seseorang siswa dapat menggunakan satu kerangka yang dikembangkan oleh Biggs \& Collins (Appulembang, 2017; Soemantri, 2018) yang disebut Taksonomi SOLO (Structure of Observed Learning Outcomes). Kerangka ini didesain sebagai alat evaluasi tentang kualitas respons siswa terhadap suatu tugas atau usaha dalam menyelesaikan permasalahan (Biggs and Collins (1982). Taksonomi SOLO terdiri dari lima level yaitu prastruktural, unistruktural, multistruktural, relasional, dan extended abstract.

Nengsih et al. (2018) mengatakan bahwa pembelajaran matematika memiliki hubungan yang sangat erat dengan gaya kognitif karena dalam kegiatan belajar siswa harus mampu mengolah informasi secara sistematis. Selain daripada itu hal ini juga dipertegas oleh penelitian Siswono (dalam Warli, 2013) menjelaskan bahwa salah satu penyebab rendahnya kemampuan memecahkan masalah adalah dalam merencanakan pemecahan masalah tidak dibahas strategi-strategi yang bervariasi atau yang mendorong keterampilan berpikir kreatif untuk menemukan jawaban masalah.

Penelitian sebelumnya yang mendasari penelitian ini terkait pemecahan masalah dan gaya kognitif konseptual tempo memberikan hasil yang beraneka ragam. Adapun penelitian yang ada barulah sebagaian besar meneliti mengenai kemampuan pemecahan masalah siswa bergaya kognitif konseptual tempo yaitu reflektif dan impulsive. Seperti halnya Appulembang (2017) meneliti profil pemecahan masalah aljabar siswa bergaya kognitif konseptual tempo yang menyatakan bahwa siswa dalam penyelesaian masalah aljabar siswa dengan gaya kognitif reflektif dan impulsif memiliki perbedaan dalam mencapai level taksonomi SOLO yang berbeda. Ditemukan juga bahwa subjek reflektif dan impulsif menunjukkan kecenderungan pemecahan masalah yang sama pada keempat level taksonomi SOLO pada soal persamaan linear satu variabel dan berbeda pada tingkat extended abstrak pada soal persamaan linear dua variabel.

Miatun dan Nurafni (2018) meneliti tentang kemampuan berpikir kreatif matematis pada siswa bergaya kognitif reflektif dan impulsif. Hasil penelitiannya mengatakan bahwa pada kemampuan berpikir kreatif mahasiswa reflektif dan impulsif memiliki perbedaan dalam aspek berpikir kreatifnya. Pada mahasiswa gaya kognitif reflektif aspek berpikir kreatif yang mampu dicapai dengan baik adalah kelancaran (fluency) dan aspek 
keterincian (elaboration), sedangkan pada mahasiswa impulsif belum mampu memenuhi aspek tersebut dengan baik. Warli (dalam Aini, Murtianto, \& Prasetyowati, 2019) menyatakan bahwa siswa dengan gaya kognitif reflektif memiliki kemampuan matematika lebih baik bila dibandingkan dengan siswa bergaya kognitif impulsif serta karakteristiknya dalam menyelesaikan soal dalam waktu relatif lama dan cenderung berhati-hati. Hal ini menjadi pemicu mereka melakukan penelitian untuk mengetahui dan mengkaji lebih dalam mengenai kemampuan spasial siswa dengan gaya kognitif reflektif dalam menyelesaikan soal.

Demikian halnya hasil penelitian oleh Fadiana (2016) bahwa siswa bergaya kognitif impulsif memiliki nilai rata-rata pemecahan masalah lebih rendah dibandingkan siswa reflektif karena karakteristiknya dalam menyelesaikan masalah relatif singkat dan cenderung salah dalam menyelesaikan masalah. Berbeda halnya dengan penelitian yang dilakukan oleh Hayuningrat \& Listiawan (2018) yang mendeskripsikan proses berpikir siswa dengan gaya kognitif reflektif dalam memecahkan masalah matematika generalisasi pola. Dalam penelitian terdahulu yang relevan terkait dengan kemampuan pemecahan masalah siswa bergaya kognitif konseptual tempo yang kebanyakan memunculkan siswa reflektif dan impulsive dalam hal membandingkannya.

Belum adanya penelitian yang meneliti khusus mengenai kemampuan siswa impulsif yang berhasil mencapai tingkat pemecahan masalah yang lebih tinggi. Setiap siswa meskipun dengan karakteristik yang berbeda dari yang lainnya, bukan berarti tidak dapat mencapai tingkat pemecahan masalah yang tinggi. Justru hal yang baik ini perlu diungkapkan agar dapat menjadi motivasi bagi yang berkarakteristik gaya kognitif yang sama untuk bisa berjuang dengan baik dan memperbaiki kekurnagan yang ada.

Perlunya sebuah penelitian untuk mengkaji karakteristik subjek gaya kognitif impulsif dalam memecahkan masalah, diperlukan suatu pembuktian juga bahwa subjek impulsif dapat mencapai level respon yang sama dengan yang dicapai subjek reflektif. Hal ini bertujuan untuk menjawab tantangan dan menunjukkan bahwa siswa impulsive dapat menyelesaikan masalah tingkat tinggi. Pemecahan masalah tentu dapat dikatakan memiliki keterkaitan erat dengan kemampuan matematika seseorang. Sehingga dapat dikatakan bahwa orang yang memiliki kemampuan matematika yang bai dapat menyelesaikan masalah aljabar dengan baik juga (Wahyuniar, Shofia, dan Rochana, 2018). Kemampuan ini pun dapat dihubungkan dengan kemampuan berpikir seseorang 
dalam berespon. Karakteristik seseorang dalam menerima, menganalisis dan memberikan respon terhadap apa yang diberikan disebut gaya kognitif. Salah satunya adalah gaya kognitif konseptual tempo yaitu menunjukkan tempo atau kecepatan dalam berpikir dan berespon. Subjek dengan gaya kognitif impulsive yang memiliki ciri sangat cepat dalam berespon pertanyaan-pertanyaan yang diajukan, dan cenderung salah, dikatakan memiliki kemampuan yang rendah dan dikatakan memiliki kemampuan konsentrasi yang kurang dalam kelas serta tidak berpikir mendalam, tingkat ingin tahunya biasa saja dalam menyelesaikan masalah (Rahmatina, dkk, 2014).

Oleh karena itu, penelitian ini bertujuan untuk mengidentifikasi dan mendeskripsikan kemampuan pemecahan masalah siswa dengan gaya kognitif impulsif berdasarkan taksnomi SOLO. Penelitian ini menggunakan taksonomi SOLO karena ini merupakan salah satu alat evaluasi tentang kualitas respon siswa terhadap suatu tugas atau usaha menyelesaikan masalah. Taksonomi SOLO juga membuat level berpikir, dan hal ini dapat menampilkan kemampuan kognitif siswa dalam menyelesaikan masalah.

\section{METODE PENELITIAN}

Jenis penelitian ini adalah penelitian deskriptif kualitatif, yang bertujuan untuk mengidentifikasi dan mendeskripsikan kemampuan pemecahan masalah siswa dengan gaya kognitif impulsif. Subjek dalam penelitian ini adalah 33 orang siswa kelas X di SMA Negeri 1 Tana Toraja pada semester genap. Siswa dikelompokkan berdasarkan gaya kognitif menggunakan instrumen penilaian. Dari kelompok gaya kognitif impulsif dipilih 2 orang mahasiswa sebagai perwakilan subjek. Pemilihan subjek juga berdasarkan kesetaraan kemampuan awal, dan kemampuan berkomunikasi.

Instrumen yang digunakan dalam penelitian ini yaitu: Tes MFFT, Tes superitem, dan pedoman wawancara. Tes MFFT (Matching Familiar Figure Test) adalah instrumen yang dikembangkan oleh Warli (2013), yang merupakan instrumen khas untuk menilai gaya kognitif impulsif-reflektif. Instrumen tes terdiri dari 13 item soal yang terbagi atas gambar standar (baku) terdiri dari satu gambar dan gambar variasi (stimulus) yang terdiri dari delapan gambar. Tes superitem merupakan soal yang memuat soal-soal aljabar yaitu sistem persamaan linear dua variabel (SPLDV) yang diuraikan ke dalam empat kategori tingkat berpikir pemecahan masalah berdasarkan taksonomi SOLO yaitu unistruktural, multistruktural, relational, dan extended abstract, sedangkan pedoman wawancara yang 
bertujuan untuk menelusuri dan mengklarifikasi jawaban subjek secara mendalam, dan memaparkan bagaimana subjek menjabarkan proses pemecahan masalah dan tingkatan berpikirnya.

Pengumpulan data menggunakan metode triangulasi, yaitu dengan strategi pengecekan derajat kepercayaan hasil penelitian (Moleong, 2013). Dalam penelitian ini dilakukan pencocokan data hasil jawaban tes tertulis tes superitem dan data hasil wawancara. Keabsahan data (valid) terjadi apabila terdapat kesamaan di antara kedua hasil data tersebut, sehingga dapat dinyatakan sebagai data yang valid. Hal ini sesuai dengan pendapat Miles dan Huberman (dalam Sugiyono, 2013), yang menyatakan bahwa aktivitas dalam analisis data kualitatif dilakukan secara interaktif dan berlangsung secara terus menerus sampai tuntas, sehingga membentuk data yang berpola.

Dalam penelitian ini proses analisis data dilakukan dari awal pengumpulan sampai penelitian di lapangan telah dilakukan. Analisis dimulai sejak pemberian tes MFFT, tes superitem, sampai kepada wawancara. Masing-masing subjek penelitian diberikan tes superitem yaitu tes yang dikembangkan berdasarkan taksonomi SOLO untuk memantau kemampuan kognitif siswa dalam pemecahan masalah, lalu dilakukan wawancara, sehingga data terkumpul yaitu hasil pekerjaan siswa dan transkrip wawancara. Langkah selanjutnya adalah reduksi data dengan cara mengelompokkannya ke dalam empat kategori tingkat berpikir pemecahan masalah berdasarkan taksonomi SOLO. Setelah data dikelompokkan lalu disajikan dan menarik kesimpulan akhir. Tabel 1 menunjukkan kriteria penentuan calon subjek penelitian.

Tabel 1. Kriteria Penentuan Calon Subjek Penelitian

\begin{tabular}{cc}
\hline $\begin{array}{c}\text { Skor skala gaya kognitif konseptual } \\
\text { tempo }\end{array}$ & Kategori gaya kognitif konseptual \\
tempo
\end{tabular}

Keterangan:

$\mathrm{t}$ : rataan waktu subjek dalam menjawab tes MFFT

$\mathrm{f}$ : rataan pilihan jawaban subjek dalam menjawab tes MFFT

$\mathrm{t}$ median : median dari rataan waktu seluruh subjek 
f median : median dari rataan pilihan jawaban seluruh subjek

\section{HASIL DAN PEMBAHASAN}

\section{Pengelompokan Gaya Kognitif Konseptual Tempo}

Setiap siswa kelas X diberikan tes MFFT (Matching Familiar Figure Test) untuk mengelompokkan subjek ke dalam gaya kognitif cepat akurat, impulsif, reflektif, dan lambat tidak akurat. Berdasarkan hasil tes tersebut, skor masing-masing siswa dianalisis yang menghasilkan rataan waktu dan rataan pilihan. Diperoleh rataan waktu sebesar 73.94 detik dan median rataan pilihan sebesar 1.92 pilihan. Kedua data ini akan dijadikan standar untuk mengelompokkan gaya kognitif siswa ke dalam empat kategori sebagaimana disajikan pada Tabel 2.

Tabel 2. Pengelompokkan Siswa berdasarkan Hasil Tes MFFT

\begin{tabular}{cll}
\hline No & Kategori Gaya Kognitif & \multicolumn{1}{c}{ Nomor Subyek Penelitian } \\
\hline 1 & Cepat akurat & $\mathrm{S} 1, \mathrm{~S} 4, \mathrm{~S} 6, \mathrm{~S} 7, \mathrm{~S} 15, \mathrm{~S} 20, \mathrm{~S} 25, \mathrm{~S} 28$ \\
2 & Impulsif, & $\mathrm{S} 2, \mathrm{~S} 3, \mathrm{~S} 5, \mathrm{~S} 8, \mathrm{~S} 9, \mathrm{~S} 11, \mathrm{~S} 16, \mathrm{~S} 17, \mathrm{~S} 18, \mathrm{~S} 21, \mathrm{~S} 32$ \\
3 & Reflektif, & $\mathrm{S} 13, \mathrm{~S} 14, \mathrm{~S} 23, \mathrm{~S} 24, \mathrm{~S} 26, \mathrm{~S} 27, \mathrm{~S} 33$ \\
4 & Lambat tidak akurat & $\mathrm{S} 10, \mathrm{~S} 12, \mathrm{~S} 19, \mathrm{~S} 22, \mathrm{~S} 29, \mathrm{~S} 30, \mathrm{~S} 31$ \\
\hline
\end{tabular}

Berdasarkan Tabel 2, distribusi kategori siswa cukup merata, dimana dari 33 orang siswa terdapat 8 orang siswa dengan gaya kognitif cepat akurat, 9 orang impulsif, 9 orang reflektif, dan 7 orang lambat akurat. Sehubungan dengan tujuan dan kebutuhan subjek penelitian yaitu siswa impulsif, dengan mempertimbangkan kemampuan awal, kemampuan berkomunikasi/mengekspresikan pikirannya dan kesediaan subjek, maka diambillah dua subjek yang bergaya kognitif benar-benar impulsif yaitu S11 (Impulsif01) dan S17 (Impulsif-02). Kedua subjek ini lalu diberikan tes superitem dan wawancara untuk memperjelas jawaban tertulisnya. Data yang diperoleh kemudian ditampilkan dan dianalisis untuk kemudian disimpulkan.

\section{Kemampuan Pemecahan Masalah Berdasarkan Tes Superitem}

Berdasarkan tes superitem yang diberikan kepada kedua subjek terpilih, maka diperoleh hasil pada Tabel 3. 
Tabel 3. Lembar Centang Hasil Tes Superitem Subjek

\begin{tabular}{ccccc}
\hline \multirow{2}{*}{ Subjek } & \multicolumn{4}{c}{ Level Berpikir Tes Superitem } \\
\cline { 2 - 5 } & Unistruktural & Multistruktural & Relasional & Extended Abstrak \\
\hline Impulsif-01 & $\sqrt{ }$ & $\sqrt{ }$ & $\sqrt{ }$ & $\sqrt{ }$ \\
Impulsif-02 & $\sqrt{ }$ & $\mathrm{X}$ & $\mathrm{X}$ & $\mathrm{X}$ \\
\hline
\end{tabular}

Pada Tabel 3 tampak perbedaan hasil pada subjek Impulsif-01 dan Impulsif-02. Subjek Impulsif-01 dapat menyelesaikan soal pemecahan masalah SPLDV dengan tepat pada semua level. Dilain pihak, subjek Impulsif-02 hanya mampu menyelesaikan tes pada level unistruktural saja. Hal ini menunjukkan perbedaan kemampuan pemecahan masalah dari subjek Impulsif.

Berikut ini hasil penyelesaian pemecahan masalah tes superitem dari subjek impulsif-01 pada permasalahan SPLDV, sebagaimana disajikan pada Gambar 1.

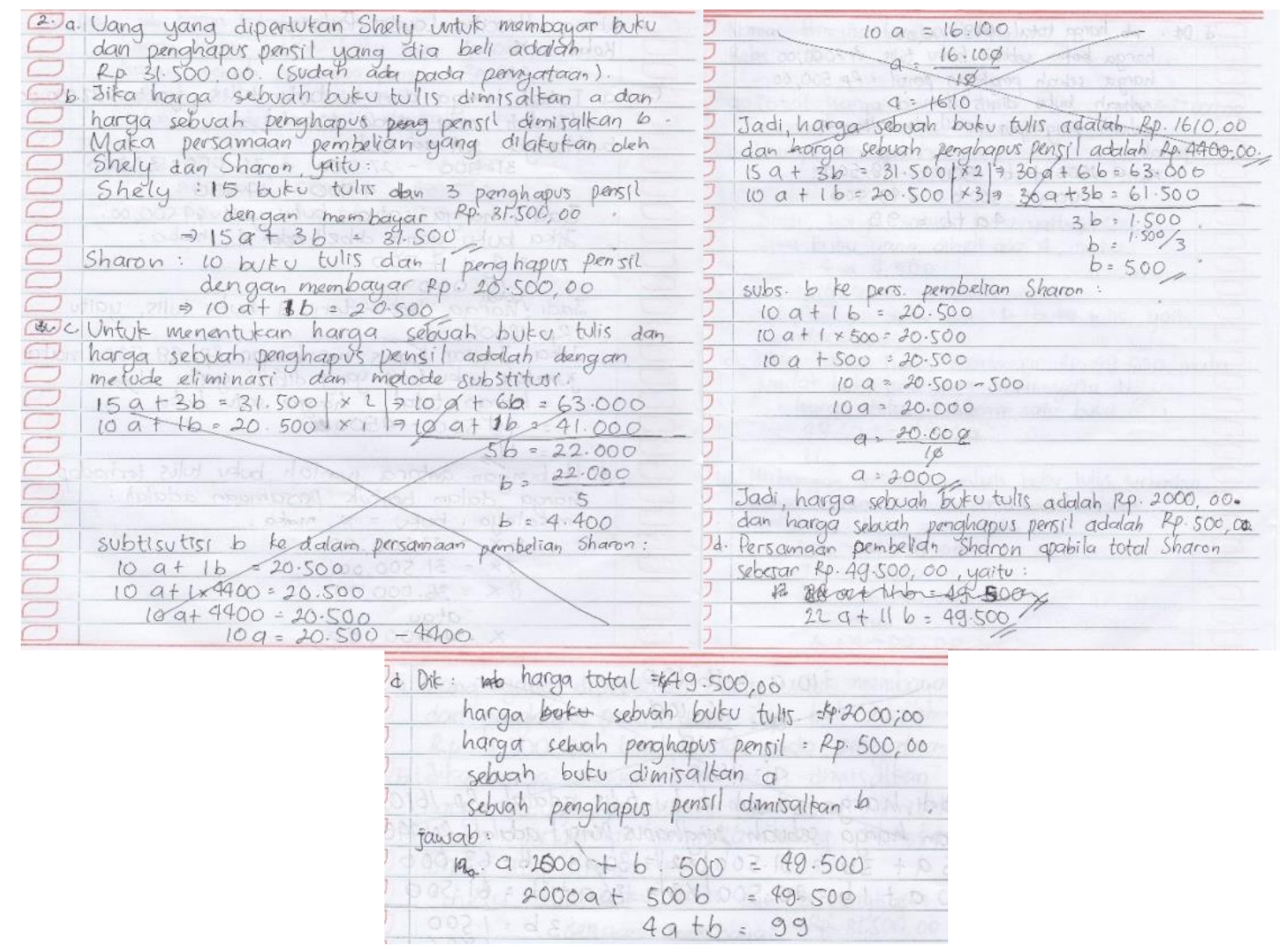

Gambar 1. Lembar Kerja Tes Superitem Subjek Impulsif-01

Pada Gambar 1, tampak bahwa subjek Impulsif-01 mampu menyelesaikan soal pada semua level soal yaitu unistructural, multistruktural, relasional dan extended abstract dengan tepat. Hasil penyelesaian menunjukkan tidak adanya kendala dari subjek 
Impulsif-01 dalam menyelesaikan masalah. Subyek dapat menjawab dengan lancar dengan menunjukkan alur pemecahan masalah berdasarkan apa yang diketahui dari soal.

Namun pada Gambar 1, juga tampak bahwa subjek Impulsif-01 pada bagian (c) terdapat penggantian jawaban oleh subjek. Subjek telah menyelesaikan masalah dengan menggunakan metode eliminasi dan substitusi dan mendapatkan jawaban. Namun terlihat pada jawaban yang dicoret terlihat kesalahan perhitungan pada langkah metode eliminasi sehingga mendapatkan jawaban yang disadari salah oleh subjek sehingga dia menyelesaikan kembali dengan metode eliminasi sampai substitusi sampai mendapatkan jawaban yang baru dan dianggap benar. Begitupun halnya saat subjek menyelesaikan soal bagian (d), awalnya menuliskan $22 \mathrm{a}+11 \mathrm{~b}=49.500$ namun setelah mengulangi kembali mendapatkan jawaban yang berbeda.

Guna memperoleh data valid dan penjelasan yang lebih rinci dari subjek, maka dilakukan wawancara. Pada hasil wawancara subjek Impulsif-01, subjek dapat menyelesaikan seluruh level berpikir pemecahan masalah terkait SPLDV dengan lancar, tepat, dan dalam waktu yang singkat. Pada level unistructural dan multistruktural subjek menyatakan mengerti dan mengatakan permasalahan tersebut masih gampang untuk diselesaikan. Pada level relasional, subjek menyatakan kesanggupan menyelesaikan apabila yang diminta menggunakan persamaan yang lain untuk substitusi. Pada level extended abstrak pun, subjek dapat menyelesaikan meskipun subjek menyelesaikan sebanyak dua kali lalu menetapkan jawabannya seperti yang terjadi pada level relasional. Subjek impulsif-01 menyatakan bahwa permasalahan extended abstrak termasuk sukar baginya karena terdapat dua variabel.

\section{Hasil Pemecahan Masalah Subjek Impulsif-02}

Berikut ini hasil penyelesaian pemecahan masalah tes superitem dari subjek impulsif-02 pada permasalahan SPLDV. Pada Gambar 2, tampak bahwa subjek Impulsif02 mampu menyelesaikan soal pada level unistructural saja, sedangkan untuk penyelesaian soal level multistruktural, relasional dan extended abstrak masih belum dapat terselesaikan dengan tepat oleh subjek. Pada level multistruktural, subjek tidak menjawab sesuai pertanyaan, dan dengan langsung menuliskan harga sebuah buku dan sebuah penghapus tanpa memberikan nilainya diperoleh dari mana. Pada level relasional, terlihat subjek tidak menggunakan informasi sebelumnya untuk menyelesaikan 
permasalahan, namun dengan melakukan cara coba-coba sehingga menemukan suatu nilai tertentu untuk menyesuaikan dengan informasi yang diberikan yaitu total pembayaran. Pada level extended abstract, subjek pun tidak menjawab sesuai dengan apa yang diminta oleh soal.

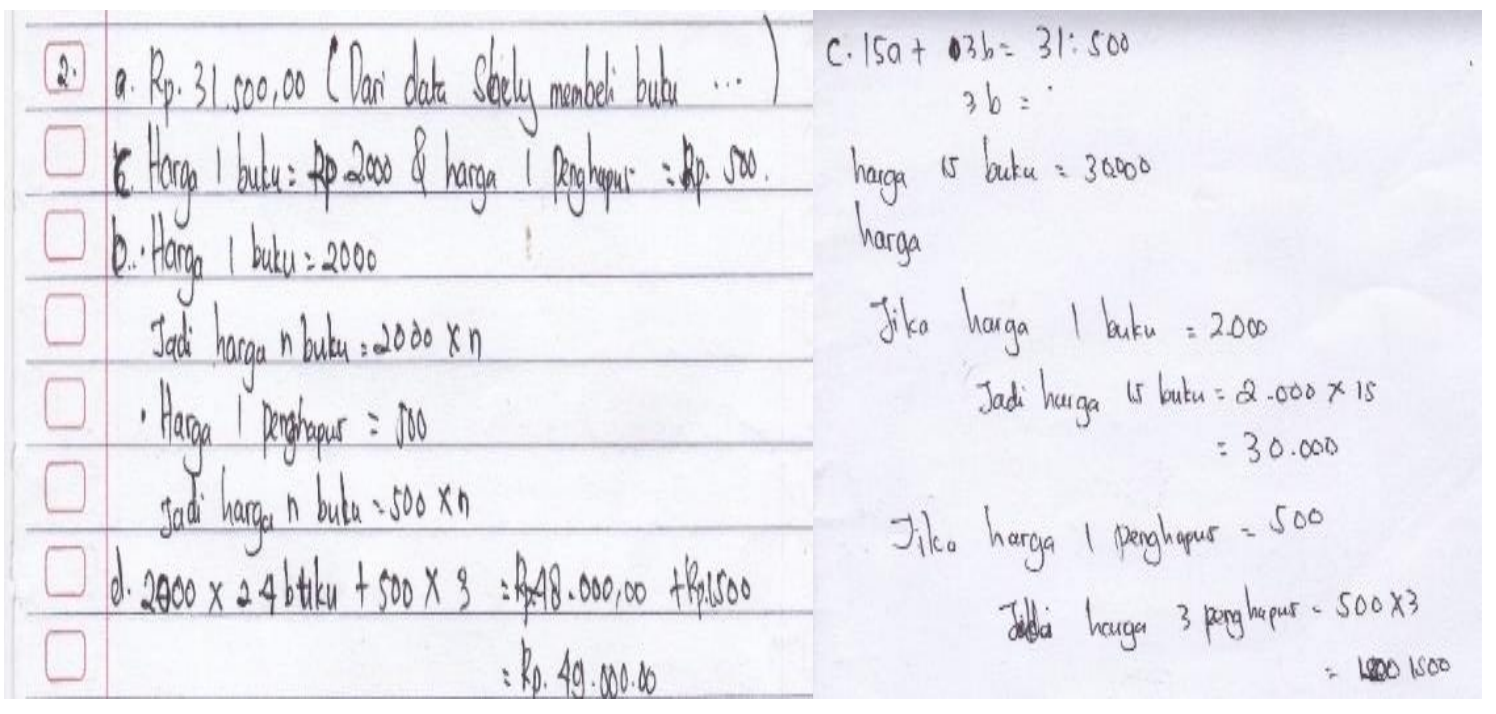

Gambar 2. Lembar Kerja Tes Superitem Subjek Impulsif-02

Pada hasil wawancara subjek Impulsif-02, subjek hanya dapat menyelesaikan pemecahan masalah terkait SPLDV pada level Unistructural saja. Subjek menyelesaikan permasalahan dengan lancar, tepat, dan dalam waktu yang singkat dengan melihat langsung pada informasi yang diberikan. Subjek fokus pada satu strategi atau solusi seperti halnya pada subjek impulsif-01 sebelumnya.

Berdasarkan hasil tes superitem pemecahan masalah dan wawancara yang dilakukan kepada kedua subjek impulsif, maka didapatkan karakteristik pemecahan masalah dari masing-masing subjek. Pada tingkat Unistructural, Subjek Impulsive-01 dan Subjek Impulsive-02 mampu menyelesaikan soal dengan tepat dan cepat dengan cara melihat langsung informasi pada soal. Subjek fokus pada satu strategi atau solusi. Dilain pihak, pada tingkat lainnya kedua subyek menunjukkan kemampuan yang berbeda.

Pada tingkat Multistruktural, Subjek Impulsive-01 mampu menyelesaikan soal dengan tepat dan cepat. Subjek menggunakan apa yang telah diberikan pada soal, mengelompokkan penggalan yang ada, dapat memecahkan masalah dengan menggunakan informasi dengan strateginya yaitu pemisalan. Dilain pihak, Subjek Impulsive-02 tidak mampu menyelesaikan soal dengan tepat. Subjek menggunakan 
informasi yang ada dan mengelompokkannya untuk mencoba menyelesaikan. Namun, subjek tidak dapat menyelesaikan apa yang diminta yaitu membuat persamaan, dia tidak mengerti maksud dari persamaan, serta tidak ingin berlama-lama menyelesaikan bagian yang memang dia sudah tahu tidak mengerti.

Pada tingkat Relasional, Subjek Impulsive-01 mampu menyelesaikan soal dengan tepat dan cepat. Subjek menggunakan informasi sebelumnya yaitu persamaan pembelian pada soal sebelumnya, dia memadukan informasi yang ada, menghubungkan kedua persamaan itu, lalu melakukan eliminasi dan substitusi dalam persamaan linear dua variabel sehingga menghasilkan nilai dari variabel yang ditanya. Meskipun subjek menyelesaikan soal sebanyak dua kali karena kurang teliti dan terburu-buru. Dilain pihak, Subjek Impulsive-02 tidak mampu menyelesaikan soal dengan tepat. Subjek menggunakan informasi yang ada yaitu informasi tentang pembelian meskipun tidak dapat menyusunnya ke dalam bentuk persamaan yang tepat. Subjek melakukan perhitungan dengan cara mencoba-coba, memasukkan nilai pada pembelian yang ada.

Pada Tingkat extended abstract, Subjek Impulsive-01 mampu menyelesaikan soal dengan tepat, dan cepat. Subjek mengakui tingkat kesulitan soal ini, karena terburu-buru dan merasa kurang tepat alhasil subjek menyelesaikannya sebanyak dua kali lalu yakin dengan jawabannya yaitu menyatakan persamaan yang diminta. Subjek menggunakan informasi sebelumnya, menghubungkannya, menyusun dugaan dengan pemisalan untuk menyusun persamaan yang diminta. Subjek tidak memerlukan waktu yang lama. Dilain pihak, Subjek Impulsive-02 tidak mampu menyelesaikan soal dengan tepat, dikatakan bahwa soal ini tidak gampang, dan subjek tidak mengerti apa yang dimaksudkan soal tentang persamaan. Subyek tidak ingin menghabiskan waktu untuk menyelesaikan soal yang tidak dipahami, serta tidak dapat menjelaskan hubungan dari beberapa informasi yang ada. Subjek menggunakan informasi yang ada dan melakukan coba-coba (dugaan) untuk menyelesaikan meski tidak tepat.

Berdasarkan hasil penelitian Rahmatina et al (2014), dinyatakan bahwa dalam suatu pemecahan masalah, subjek impulsif pada umumnya tidak memiliki pemikiran yang mendalam, tidak memiliki keingintahuan yang tinggi, serta tidak menganggap masalah yang sulit sebagai sebuah tantangan dan memilih meninggalkannya. Hal ini hanya didapati pada subjek impulsif-02. Pada subjek impulsif-01 terlihat bahwa dia mampu menyelesaikan semua level berpikir dari pemecahan masalah SPLDV dengan baik dan 
tepat dalam waktu yang singkat. Didapati pula bahwa subjek impulsif-01 memeriksa jawabannya sebanyak tiga kali untuk level soal extended abstract. Hal menunjukkan adanya keingintahuan subyek untuk mendapatkan jawaban yang benar.

Beberapa hasil penelitian lain menunjukkan bahwa subjek impulsif membutuhkan waktu yang relatif singkat dalam menyelesaikan soal (Azhil \& Ernawati, 2016). Hal ini ditunjukkan oleh subjek melalui kemampuannya menjawab soal berdasarkan informasi sebelumnya, dan langsung menyelesaikan. Selain itu, subyek juga mengatakan bahwa Ia terbiasa belajar hanya dalam waktu singkat. Jika belajar terlalu lama, maka berakibat kepada kebosanan.

Seperti halnya yang ditemukan oleh Appulembang (2017) bahwa subjek impulsif yang dapat menyelesaikan hingga tingkat abstrak ini dapat memberikan kontribusi baru bahwa juga terdapat subjek impulsif yang dapat berpikir abstrak yaitu tingkat tertinggi dari taksonomi SOLO. Meskipun hasil penelitian Soemantri (2018) mengemukakan bahwa tingkat kesalahan siswa dalam menyelesaikan soal semakin tinggi seiring dengan semakin cepat (impulsif) siswa menyelesaikan sebuah soal. Berdasarkan hasil penelitian ini, ditemukan bahwa subjek impulsif-01 dapat menyelesaikan pemecahan masalah dengan tepat dan tuntas sampai pada level extended abstract, meskipun tetap memiliki ciri-ciri impulsif pada umumnya yaitu kecepatan menjawab permasalahan yang berakibat pada ketidaktelitian.

Pada subjek impulsif-01 ini, meski dari keseluruhan menunjukkan kemampuannya dalam menyelesaikan pemecahan masalah berdasarkan taksonomi SOLO dengan baik, namun ada beberapa hal yang dapat menjadi catatan. Berdasarkan adanya kejadian subjek impulsif-01 dalam menyelesaikan permasalahan tingkat relasional dan extended abstract sebanyak dua kali karena kesalahan dan keinginan untuk mengulangi dan memperbaiki itu ada. Berbeda dengan subjek impulsif-02 yang tidak ada keinginan untuk memperbaiki dan mencari tahu. Namun di sisi lain, adanya kejadian subjek impulsif-01 melakukan pemecahan masalah dua kali ini menunjukkan perbedaan dengan hasil penelitian Warli (2013) yang menyampaikan bahwa subjek impulsif tidak fleksibel atau tidak mampu membuat rencana yang berbeda-beda dalam pemecahan masalah. Nyatanya impulsif-01 dapat membuat rencana kedua dalam pemecahan masalah ini

Perbedaan kedua subjek impulsif ini dapat menjadi motivasi bagi setiap kita bahwa meskipun telah dikemukakan ciri-ciri dari impulsif dalam pemecahan masalah, namun 
tidak selamanya mereka tidak dapat berhasil menyelesaikan masalah yang ada. Hal ini memotivasi siswa dengan kemampuan impulsif lainnya bahwa mereka memiliki peluang untuk memperbaiki kelemahannya. Ketidakmampuan ini bukan disebabkan karena gaya kognitifnya semata, namun karena kurangnya kemampuan pemahaman materi. Hal ini menunjukkan adanya hambatan epistemologi pada materi yang dipelajari.

Pada level berpikir multistruktural, relasional dan extended abstract, subjek Impulsif-02 tidak dapat memahami apa yang ditanyakan. Hal ini tentu bertentangan dengan yang ditegaskan oleh Polya (dalam Akhsani \& Jaelani, 2018) bahwa langkah pertama dalam suatu pemecahan masalah adalah memahami masalah yang akan diselesaikan. Adapun penelitian Sumardi, Putra, \& Astutik (2020) mengenai proses pemecahan masalah matematika, menyatakan bahwa peserta didik berdasarkan kecerdasan majemuk, memberikan ide untuk perlu juga dipertimbangkan untuk adanya perbedaan dari kedua subjek impulsif ini dalam hal kecerdasan majemuknya.

Salah satu karakteristik yang dimiliki oleh subjek impulsif-02 yang membedakan dengan subjek impulsif-01 adalah dalam pemecahan masalah. Subjek impulsif-02 memiliki daya juang yang rendah, dan cepat menyerah terkhusus saat tidak dapat menyelesaikannya. Hal yang sama juga ditemukan oleh Miatun (2019) bahwa subjek impulsif juga cenderung lebih cepat menyerah ketika tidak bisa mengerjakan soal. subjek impulsif-02 dalam menyelesaikan soal extended abstract itu cenderung melakukan cobacoba dalam menyelesaikan soal dan cenderung salah. Hal ini pun selaras yang dikemukakan Warli (2013) bahwa siswa impulsive kurang cermat pada tahap mengerjakan (sedikit mencoba-coba), langsung mengerjakan, dan jawaban yang diperoleh banyak tetapi cenderung salah.

Selain perbedaan dari kedua subjek impulsif, ditemukan persamaan dalam menyelesaikan soal pemecahan masalah. Salah satu persamaan mereka yaitu seperti yang dikemukakan juga oleh Appulembang (2017), yaitu subjek impulsif kurang cermat dan cepat dalam menjawab masalah namun cenderung salah. Berdasarkan data yang ditemukan, maka terlihat kedua subjek sering terburu-buru dalam menyelesaikan soal, ingin cepat, meskipun sudah mengulangi tapi tetap tidak ingin berlama-lama dalam menyelesaikan soal, bahkan memilih untuk meninggalkan soal. 


\section{KESIMPULAN}

Terdapat perbedaan kemampuan pemecahan masalah pada subjek impulsif. Ciriciri subjek impulsive adalah mempunyai kemampuan untuk menyelesaikan permasalahan dengan cepat dan tepat, kurang cermat, kurang teliti, dan terkesan terburu-buru. Mereka tidak mau menghabiskan waktu yang lama untuk menyelesaikan masalah. Mereka juga tidak termotivasi untuk menyelesaikan, serta tidak ingin berlama-lama dalam menyelesaikan suatu masalah. Oleh sebab itu, mereka membutuhkan bimbingan agar dapat meningkatkan motivasi belajar, terutama untuk memahami soal agar dapat diselesaikan, dan terus mencoba sesuai dengan kemampuan yang dimiliki.

\section{REFERENSI}

Aini, Rahma Nur., Murtianto, Yanuar Hery., \& Prasetyowatu, Dina. (2019). Profil Kemampuan Spasial Ditinjau dari Gaya Kognitif Reflektif pada Siswa Kelas VIII SMP. IMAJINER: Jurnal Matematika dan Pendidikan Matematika, 1(5), 90 - 96.

Akhsani, L., dan Jaelani, A. (2018). Peningkatan Kemampuan Pemecahan Masalah Matematis Mahasiswa melalui Metode Snow Ball Throwing pada Mata Kuliah Teori Graf. KONTINU: Jurnal Penelitian Didaktik Matematika, 2 (1), 48 - 59.

Anggraeni, Anggraeni, Rusmala E., Wulan, Eka R., \& Utomo, Bendot T. (2019).

Pemecahan Masalah Polya Dari Siswa Smp Bergaya Kognitif Field Dependent Dan Field-Independent. Journal of The Indonesian Matematics Education Society, 1 (1), $11-18$.

Appulembang, Oce D. (2017). Profil Pemecahan Masalah Aljabar Berpandu pada Taksonomi SOLO Ditinjau dari Gaya Kognitif Konseptual Tempo Siswa SMA Negeri 1 Makale Tana Toraja. POLYGLOT: Jurnal Ilmiah, 13 (2), 133 - 150.

Azhik, Imam M. \& Ernawati, A. (2016). Profil Pemecahan Masalah Siswa SMP pada Materi Perbandingan Ditinjau dari Gaya Kognitif Reflektif dan Impulsif. Prosiding SENDIKMAD: Seminar Nasional Pendidikan Matematika Ahmad Dahlan, Yogyakarta, 1, $125-135$.

Erviana Tanti. (2019). Kemampuan Penalaran Matematis Siswa dalam Memecahkan Masalah Aljabar Berdasarkan Gaya Kognitif Field Independent. Alifmatika: Jurnal Pendidikan dan Pembelajaran Matematika, 1 (1), 61 - 73.

Fadiana Mu'jizatin (2016). Perbedaan Kemampuan Menyelesaikan Soal Cerita antara 
Siswa Bergaya Kognitif Reflektif dan Impulsif. JRAMathEdu: Journal of Research and Advances in Mathematics Education, 1 (1), 79 - 89.

Hayuningrat, S., \& Listiawan, T. (2018). Proses Berpikir Siswa dengan Gaya Kognitif Reflektif dalam Memecahkan Masalah Matematika Generalisasi Pola. Jurnal Elemen, 4 (2), 183 - 196.

Komalasari, Lala Intan. (2019). Analisis Kemampuan Siswa dan Guru SMK dalam Menyelesaikan Masalah Matematika. HISTOGRAM: Jurnal Pendidikan Matematika, 3 (2), 189 - 198.

Maimunah M., Purwanto P., Sa'dijah C., \& Sisworo S. (2016). Penerapan Model Pembelajaran Matematika Melalui Pemecahan Masalah untuk Meningkatkan Penalaran Matematis Siswa Kelas X-A SMA Al-Muslimun. JRPM: Jurnal Review Pembelajaran Matematika, 1(1), 17 - 30.

Miatun, A., \& Nurafni, N. (2019). Profil Kemampuan Berpikir Kreatif Matematis Ditinjau dari Gaya Kognitif Reflective dan Impulsive. Jurnal Riset Pendidikan Matematika, 6(2), 150-164

Moleong, Lexy J. (2013). Metodologi Penelitian Kualitatif (Edisi Revisi). Bandung: PT Remaja Rosdakarya.

Nengsih, L., Susiswo, S., \& Sa'dijah, C. (2018). Kemampuan Pemecahan Masalah Matematika Siswa Sekolah Dasar dengan Gaya Kognitif Field Dependent. Jurnal Pendidikan: Teori, Penelitian, dan Pengembangan, 4(2), 143 - 148.

Nurmutia, Halida E. (2019) Pengaruh Gaya Kognitif terhadap Kemampuan Pemecahan Masalah Matematis Siswa. EDUMATIKA: Jurnal Riset Pendidikan Matematika, 2(2), $98-103$.

Rahmatina, S., Sumarmo, U., \& Johar, R. (2014) Tingkat Berpikir Kreatif Siswa dalam Menyelesaikan Masalah Matematika Berdasarkan Gaya Kognitif Reflektif dan Impulsif. Jurnal Didaktik Matematika, 1 (1), 62 - 70.

Rismen, S., Juwita, R. \& Devinda, U. (2020). Profil Kemampuan Pemecahan Masalah Matematika Siswa Ditinjau dari Gaya Kognitif Reflektif. Jurnal Cendekia: Jurnal Pendidikan Matematik, 4 (1), 163 - 171

Soemantri, Sandha. (2018). Pengaruh Gaya Kognitif Konseptual Tempo Terhadap Tingkat Kesalahan Siswa. Didaktis: Jurnal Pendidikan dan Ilmu Pengetahuan, 18 
(1), $74-85$.

Sumadi, S., Putra, Teguh Y., \& Astutik, Heny S. (2020). Proses Pemecahan Masalah Matematika Siswa SMA Berdasarkan Kecerdasan Majemuk. JHM: Journal of Honai Math, 3 (2), 123 - 144

Wahyuniar, Lilia S., Shofia, Niska, \& Rochana. (2018). Proses Berpikir Aljabar Siswa MTs Kelas VIII menurut Taksonomi SOLO ditinjau dari Perbedaan Gender. AKSIOMA: Jurnal Pendidikan Matematika FKIP Univ. Muhammadiyah Metro, 7 (2), 275-282

Warli (2013). Kreativitas Siswa SMP yang Bergaya Kognitif Reflektif atau Impulsif dalam Memecahkan Masalah Geometri. Jurnal Pendidikan dan Pembelajaran Universitas Negeri Malang, 20 (2), 190 - 201.

Widjajanti, Djamilah B. (2009). Kemampuan Pemecahan Masalah Matematis Mahasiswa Calon Guru Matematika: Apa dan Bagaimana Mengembangkannya. Prosiding Seminar Nasional Matematika dan Pendidikan Matematika Jurusan Pendidikan Matematika FMIPA UNY, Yogyakarta, $402-413$. 